\title{
DRAWING UP THE FINANCIAL BUDGET IN THE CASE OF A PUBLIC TRANSPORTATION COMPANY
}

\author{
Lecturer PhD Sorin Adrian Achim, Babeş-Bolyai University of Cluj-Napoca, Romania, \\ e-mail:sorin.achim@econ.ubbcluj.ro \\ Lecturer PhD Monica Violeta Achim, Babeş-Bolyai University of Cluj-Napoca, Romania, \\ e-mail:monica.achim@econ.ubbcluj.ro \\ PhD Student Mirela-Oana Pintea, Babeş-Bolyai University of Cluj-Napoca, Romania, \\ e-mail: mirela.pintea@econ.ubbcluj.ro \\ PhD Student Alin - Ionel Ienciu, Babeş-Bolyai University of Cluj-Napoca, Romania, , \\ e-mail: alin.ienciu@econ.ubbcluj.ro
}

\begin{abstract}
The drawing up of the companies' budget represents one of the most important instruments through which is accomplished an efficieny management, the evaluation of companies' performances and personnel motivatio. Public local transportation companies usually use budgets as comparison benchmarks for the performances they obtain in their current activity. These bidgets represent an essential part in the unfolding of each company's activity. This paper presents the drawing up of the financial budgets with a public local transportation company, referring to the drawing up of purchase budgets, investments budgets and cash flows budgets.
\end{abstract}

Key words: financial management, budget, financial budget, profit center

JEL Codes: $M 41$

The major objective of each company is obtaining profit. This is the reason why special attention is paid to financial management, thus determining both the profitable activities and the less profitable ones, since managers are interested in increasing the future performances obtained from the current activity. Therefore, there it is drawn up an income and expenses budget ans there are determined a series of financial objectives to be attained.

The budgeting of the companies' activity is one of the most important instruments through which there is accomplished an efficient business management, the evaluation of the company's performance and the motivation of the employees.

If a public transportation company decided to invest time and effort in the budgeting process, this investment should be $80 \%$ from the analysis, planning and decision making activity and only $20 \%$ in the actual activity of drawing up the budget. Obtaining the optimum results in the budgeting activity implies an active collaboration among those responsible with this activity. In this sense, managers from all levels have to be involved in the budget process so that the fundamental objective is reached, that is the increase of the company's profitability.

Public transportation companies usually use budgets as benchmarks for the performances they attain in their current activity. These budgets represent an essential part in the unfolding of the activity of each company, to the extent in which performance based budgets are applied.

Financial budgets refer to the elements of the financial standing of the company and their drawing up in the case of public transportation companies is obtained using the following methodology: 


\section{A. Drawing up the purchase budgets for each profit center}

Purchases budget includes the need for inventories corresponding to each profit center (due to the type of activity, we will refer to fuel-lubricating oil inventory, respectively to the spare parts inventories).

\section{The budget of fuel- pruchase}

The (monthly and yearly) need of fuel-lubricating oils is estimated according to the fuel consumption estimated for the budget year in the budget of the operating results of each profit center. Knowing the required amount of fuel-lubricating oils, we have to determine the frequency of supplies in order to sign contracts with suppliers. The supplies frequency depends on many factors, the influence of which has to be considered in a combined manner. Some of the most important factors are:

- The storage capacity of the company - there cannot be programmed supplies larger then the storage capacity, also taking into account the inventories existing on the date of purchase;

- Transport-supply expenses - the higher these expenses, the more recommended is a lower amount of supplies and, consequently, a larger amount on each supply;

- The possible advantages negotiated with suppliers (concerning the possible discounts or payment facilities) - if, in the case of a larger amount purchased, there are certain advantages related to discounts and due time extensions and the value of these advantages surpasses the additional quantities' storage costs, then it is recommended that these quantitied should be purchases so that the company night enjoy the corresponding advantages;

- Increasing the safety inventory - which, in the case of the public transportation company, have to be represented by the amount of fuel necessary to the circulation of all the transportation means for the period required to obtain the necessary fuel. If the suppliers is form the same region and there are no problems with obtaining the required fuel inventory, the safety inventory has to be calculated for several hours. On the other hand, if there are such problems or if the supplier is in another region, the safety inventory has to be sufficient for the period required for obtaining fuel from the respective supplier or from another supplier. We believe that, in order to avoid the permanent stockpiling of a very large quanity of fuel as safety inventories. This safety inventory should cover as much as the required fuel amount for one day, since, during this period, anu transportation company is able to obtain the necessary fuel amount.

\section{The budget of spare parts purchase}

The (monthly or yearly) need of spare parts is determined according to the estimated consumption on categories. The choice of a purchase plan for spare parts is made in the same way as for fuel, constantly taking into account the advantages generated by the purchase of a larger quantity in comparison to the costs they imply. In this case also there has to be taken into account a certain safety inventory calculated on categories of spare parts according to the statistic data regarding the frequency of damages on categories and periods. Moreover, when calculating the inventory of spare parts to be purchased during a certain period of time, there has to be taken into account the major repairements program for transportation means as well, repairements that require a large amount of spare parts, but which can be accurately determined.

The rest of the inventories generally represent a small amount in the case of public transportation companies and their purchase, if necessary, may be planned according to the methodology presented for fuel, respectively spare parts.

The presentation model of purchases budget may be: 
Tabel no. 1

Budget of the purchases corresponding to Profit Center „,X” for year N

\begin{tabular}{|c|c|c|c|c|c|c|c|c|c|c|c|c|c|c|c|c|c|}
\hline \multirow{2}{*}{ Indicators ${ }^{*}$} & \multirow{2}{*}{$\begin{array}{l}\text { Total } \\
\text { year }\end{array}$} & \multicolumn{4}{|c|}{ Quarter I } & \multicolumn{4}{|c|}{ Quarter. II } & \multicolumn{4}{|c|}{ Quarter. III } & \multicolumn{4}{|c|}{ Quarter. IV } \\
\hline & & Total & Jan & Feb & Mar & $\mathrm{T}$ & A & $\mathrm{M}$ & I & $\mathrm{T}$ & I & $\mathrm{A}$ & $S$ & $\mathrm{~T}$ & $\mathrm{O}$ & $\mathrm{N}$ & $\mathrm{D}$ \\
\hline & $\ldots$ & .. & 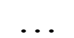 & . & 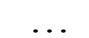 &  & . & . & &  & & & & & & 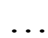 & \\
\hline
\end{tabular}

Source: authors

* Each indicator will be detailed on basic activity (public transportation), respectively on other activities (repairements, advertising etc.) according to the predictions determined on the basis of the presented procedures. The general criterion for indirect expenses distribution is represented by the incomes from services for each category (transportation, buses - town/periphery, trolley buses, other activities: repairements, advertising etc.).

\section{B. The budget of investments}

The budget of investments has to be drawn up on three investment categories:

1. investments referring to the transportation activity, expresses in the purchase of new transportation means and in the arranging of new routs or in the exchange of some transportation means (replacing buses with trolley buses or even tram cars);

2. investments for the modernization or expanding of the maintenance and repairements activity for own or third parties' transportation means, expressed in the building of new work spaces, obtaining modern equipment for workshops etc;

3. other investments of general interest for the company.

For the three categories of investments there has to be decided the beginning date, respectively the due time of the activity (if there are activities with a longer due time), the date when the transportation means are obtained, the necessary to be financed during the budget year, considered per month, as well as investments' financing sources.

The determination of the necessary financing during the budget year, separated on months, is made according to the long term general plan referring to investments and identifying the part corresponding to the budget year. For example, supposing that the time objective of a public transportation company is replacing in a three years due the transportation means, the separation on years is: during the first two years $40 \%$ and in the last year $20 \%$. Supposing that the budget year is the first year there will be determined the number of transportation means required. This number, multiplied by the price of a transportation means, will show the necessary financing and will be distributed during the budget year according to the financing possibilities. For financing investments there are used the following sources

- $\quad$ own sources expressed by the last years' profit or by the previous years profit that was no used for other purposes or by the increases in the working capital through the contribution of shareholders;

- borrowed sources expresses by various form of loans, such as long term bank loans, various types of leasing, bonds issuing. These loan forms will influence the way in which operating budgets are made, where expenses with due payments, redemptions and the interests corresponding to the desired investments are mentioned, as well as the cash flows budget, where the cash outputs corresponding to the payments for the purchases goods or for due payments, rates and interests are mentioned.

The presentation model of the investments budget may be the same as for purchases budget. 


\section{Drawing up the cash flow budget}

Drawing up the cash flows budget is made according to the following methodology (with separation on months):

\section{Proceeds budget}

\section{The budgets of proceeds from the basic activity}

The proceeds from the basic activity are generally equal and overlapped with the incomes from the basic activity, since the public transportation service is usually paid for at the same time when it is performed, or even prepaid (in the case of transportation cards). However, there may exist contracts with companies for public transportation services there are settled on a later date. Knowing the value of these services and the gap between service and payment, there can be determined the moment of the payment for these services.

\section{The budgets of proceeds from other services to third parties}

Proceeds from other services are considered to be equal and overlapped on periods of time with the incomes from these services. However, in certain cases there has to be taken into account the possible gap between the date of the service and the date of the payment.

\section{$>$ The budget of proceeds from other sources}

Proceeds from other sources are estimated according to the stipulations included in the rest of the budgets.

- Proceeds from yielding intangible assets - from the budgets of operating results;

- Proceeds from operating subventions - from the budgets of operating results;

- Proceeds from selling securities - from the budgets of financial results;

- Proceeds from long term loans - from the budgets of investments;

- Proceeds from subventions for investments - from the budgets of investments;

A special attention has to be paid to short term bank loans the obtaining of which is determined according to the statistic data corresponding to the previous periods that enable the identification of the periods during which the company needs short term loans, the average period in which it requires a loan and the necessary amounts estimated by the correction of those from the previous year by the estimated inflation index.

\section{Paymenys budget}

\section{The budget of payments to suppliers}

Has to be made ob two directions:

a) Suppliers for the current activity for which the payments are estimated according to the stipulations of the purchases budget (for inventories), respectively, the operating results budget (for non inventory products consumption), taking into account the contractual stipulations negotiated with the suppliers related to due times.

b) Suppliers of intangibles, for which the payments are estimated according to the stipulations of the investments budget, taking into account the contractual stipulations negotiated with the suppliers related to due times. 


\section{$>$ The budget of payments to employees}

Is made according to the stipulations of the operating results budgets regarding the wages estimated to be paid during the budget year (separated on months).

\section{$>$ The budget of taxes and similar payments}

Is made according to the stipulations of all the other budgets which directly or indirectly estimate all the calculation basis for various taxes and similar liabilities. For example, the VAT to be paid/recovered will result from the VAT collected, determined by the use of the VAT rate to the value of incomes from services and asset (intangible or current) sales and the deductible VAT corresponding to all the purchases stipulated in the purchases and investments budget (including the VAT corresponding to the payments for leasing contracts).

\section{$>$ The budget of payment to shareholders}

This is made according to the possible dividends estimated to be paid during the following year and the period in which these dividends are to be paid.

\section{The budget of bank loans reimbursement or other loan categories}

In the case of short term bank loans, the reimbursements will be equal to the amounts received, adding the interests estimated according to a medium interest rate for this type of loans, as well as according to the estimated average duration of obtaining these loans.

In the case of long term bank loans, the corresponding reimbursements and interests will be estimated according to the actual reimbursement plan for the loans in progress and according to the plan foreseen for those loans that are estimated to be obtained during the following year.

The possible proceeds or payments that may be predicted are going to be estimated in the budget according to the special circumstances for the economic operations they generate.

The presentation model of cash flows may be the one of the operating results.

From the issues we presented there can be drawn the conclusion that public transportation companies are able to control their future financial performances with the help of the management throug budgets, these being instruments for planning and controlling the financial performances achieved by a company.

Thsi article presents the drawing up process of budgets fpr three significant activities in the case of a public transportation company: purchases, investments and cash flows. Obtaining the equilibrium between incomes and expenses in the case of these activities has to characterize the activity unfolded in the case of any company in general, respectively in the case of a public transportation company in particular. The harmonization of incomes and expenses is made with the help of the budget, as prediction instrument for the results obtained by a company during the fiscal period.

Financing the purchases and investments of the company as a whole and of each profit center implies the existence of liquidities that may be obtained from the operating activity, from shareholders or from loans. The level of these expenses is very important in the drawing up of cash flows budgets. The unity of the budget for profit centers and for the company as a whole is ensured by the cash flows budget, a budget which provides a general image over the required financing for the budget period.

The coherence of the activities unfolded in the case of a public transportation company for the purpose of increasing profitability, as previously mentioned, is obtained through the drawn up 
budgets. Budgets have to role of dimensioning a minimum efficiency and profitability level for the company as a whole and for each profit center.

The budget of each profit center ensures the adequate administration of the available resources so that these are able to enhance their contribution to reaching the objectives determined through the general budget of the company.

As a conclusion, the integrated budget system drawn up at the level of a public transportation company represent the financial expression of the general objectives and development strategies of the company for a period of one year. The budget process stimulates managers to foresee all the problems prior to their occurrence and, consequently, to avoid making hasty decisions in the case of unforeseen future circumstances.

\section{References}

1. Matthew Andrews - Authority, acceptance, ability and performance-based budgeting reforms, International Journal of Public Sector Management no.17/2004, p.332-344, available in Emerald data base.

2. Sorin B. - Contabilitate managerială. Aspecte teoretice şi practice, Economică Publishing House, Bucureşti, 2006.

3. Fătăcean Ghe. - Contabilitatea managerială şi Controlul de gestiune, Alma Mater Publishing House, Cluj-Napoca, 2006.

4. Charles T. Horngren, Srikant M. Datar, George Foster - Contabilitatea costurilor, o abordare managerială, ediția a XI -a,Arc Publishing House, Chişinău, 2006.

5. Nace R. Magner, Gary G. Johnson, Harold T. Little, A. Blair Staley, Robert B. Welker - The case for fair budgetary procedures, Managerial Auditing Journal no. 21/2006, p. 408-419, available in Emerald data base.

6. Mu iu A., Muresan M. - Contabilitate manageială, Risoprint Publishing House, ClujNapoca, 2006.

7. Robert C. Rickards - An endless debate: the sense and nonsense of budgeting, International Journal of Productivity and Performance Management no.57/2008, p.569-592, available in Emerald data base.

8. Jacob M.Rose - Performance evaluation based on financial information: how managers use situational informations?, Managerial Finance no. 30/2004, p.46-65, available in Emerald data base.

9. Kirstin Steele - Are budget limitation real? Perspective, perceptions and a plan, The Bottom Line: Managing Library Finances no. 21/2008, p.85-87, available in Emerald data base.

10. Tabără N. - Modernizarea contabilități işi controlului de gestiune, Tipo Moldova Publishing House, Iaşi, 2006. 